\title{
Short-term effects of simulated bad weather conditions upon the behaviour of food-storer honeybees during day and night (Apis mellifera carnica Pollmann)
}

\author{
Karl Crailsheim*, Ulrike Riessberger, Birgit Blaschon, \\ Richard Nowogrodzki, Norbert Hrassnigg
}

Institut für Zoologie an der Karl-Franzens-Universität, Universitätsplatz 2, A-8010 Graz, Austria

(Received 28 September 1998; accepted 11 April 1999)

\begin{abstract}
In an observation hive with about 5000 bees, food-storers were classified by their behaviour (taking food from foragers and transporting it to the food-storing region) and then observed during day and night under good and bad (rainy) weather conditions. All food-storers were 13-19 days old. They were highly active at times of nectar flow, spending most of their time on the dance floor. At times of no food income, they stayed mostly in the broodnest and on the food stores, and were inactive $70 \%$ of the time, which might save energy for the colony; they did not take over any duties from other temporal castes. A pronounced day and night rhythm in food-storer behaviour was recorded only when there was a nectar flow. Food donations and receptions were most pronounced on good weather days, but regardless of weather and time of the day these mostly occurred in the broodnest. The importance of these patterns is discussed. Inra/DIB/AGIB/Elsevier, Paris
\end{abstract}

social behaviour / division of labour / day and night / weather

\section{INTRODUCTION}

Under normal colony conditions, a honeybee worker passes through a sequence of different task-performing stages during her adult life $[23,24]$. Bees start with the cleaning of cells when they are newly emerged, followed some days later by a period of broodcare activity. When workers are middle-aged (10-20 days old), some produce wax and build combs, some work as foodstorers - they receive nectar and honey dew from foragers, distribute the received food to other bees and store it in combs [22] - and some pack pollen and clean debris. Around the 20th day of adult life they develop into

\footnotetext{
* Correspondence and reprints

E-mail: karl.crailsheim@kfunigraz.ac.at
} 
foragers. The workers' temporal changes in labour activities correlate with a spatial shift from the central broodnest to the peripheral food storage areas and finally to the outside of the nest $[5,12,17,18,21]$.

Riessberger and Crailsheim [16] showed that conditions that prevent foraging (rain) reduce the broodcare behaviour of nurseaged bees, even in the first $24 \mathrm{~h}$. This reduction could be caused by the decreasing reserves of pollen as the raw material for the production of brood food, or by a generally reduced trophallactic flow of food. After the foragers, the food-storers are the first to be affected by reduced food income.

This study is part of a series investigating spatial distribution and behavioural patterns of different temporal castes depending on day and night and on environmental impacts. In particular, we wanted to determine whether food-storers have trophallactic contacts in the broodnest and whether these are affected by reduced food income of the colony. We also wanted to find out if there is any overlapping of duties of nurses and food-storers, and if a lack of food-storing duties prompts the food-storers to take over other duties or if their periods of inactivity increase, as is the case for unemployed foragers. Third, we investigated how a short period of no food income affected the daynight rhythm of food-storer behaviour.

\section{MATERIALS AND METHODS}

\subsection{Colony and hive}

In the summer of 1996 a colony of honeybees (about 5000 bees, Apis mellifera carnica Pollmann) was established in an observation hive with walls of glass [7] and three vertically arranged combs ( 22 by $42 \mathrm{~cm}$ ). The hive was located in a closed room on the top floor of the Zoological Department of the Karl-FranzensUniversity, Graz. The hive entrance was a transparent plastic tube $(\varnothing 40)$ that led into the natural environment through a chamber where rain could be simulated [16]. The room temperature was kept constant at about $23^{\circ} \mathrm{C}$; red light was used for observations. This colony was also used during the same period for the observations of nurses and foragers reported by Riessberger and Crailsheim [16].

A queen excluder was fixed above the lowest comb to prevent the queen from laying eggs in the cells nearest the hive entrance. The lowest comb was mostly empty and was used as the dance floor by foragers. The middle comb contained most of the broodnest. The upper comb contained some brood surrounded by the food stores. Three temperature sensors were installed inside the hive: one in the broodnest, one at the honey stores and one at the lowest comb. Temperatures were recorded at the beginning, in the middle and at the end of each observation period.

The perimeter of the broodnest, food stores and 'empty comb' area was marked every day on the glass walls of the hive to simplify the recordings of the bees' locations. We classified all areas that were not food stores or brood (including the space between combs) as empty comb. The largest area of empty comb was the lower comb with the dancing floor.

Thirty newly emerged, marked bees were introduced into the observation hive every third day before and during the observations. These bees, descended from different colonies, had emerged in an incubator $\left(34^{\circ} \mathrm{C}, 60 \% \mathrm{RH}\right)$ during the preceding $12 \mathrm{~h}$ and been marked according to a special number and colour code. These introductions provided a series of marked bees of known, different ages. To identify which of the marked bees were acting as food-storers, the trophallactic activities on the dance floor were observed. Forager bees were marked with colour at an artificial food source $20 \mathrm{~m}$ from the hive. Bees marked with the number and colour code that received nectar from foragers for more than $5 \mathrm{~s}$ on the dance floor were classified as foodstorers. These observations were performed on days with good weather conditions; they lasted for $1 \mathrm{~h}$ and were carried out just before the behavioural observations started.

\subsection{Weather conditions}

To investigate differences in the behaviour of food-storer bees depending on day versus night and on weather, both of which affect the influx of food into the colony, we observed the bees over a 3-week period under similar colony conditions. Bad weather was simulated by artificial rain which prevented the foragers from leaving the 
hive. Good weather days were defined as those when there was much foraging activity, if necessary supported by providing the bees with a 1 molar sucrose solution at an artificial feeder $20 \mathrm{~m}$ from the observation hive. Bad weather days were always simulated, even when there was natural rain. The bees were confined to the hive by the 'rain machine' described by Riessberger and Crailsheim [16]. It was turned on approximately every second day for $24 \mathrm{~h}$ at a time, starting at 02.00 hours (after a night observation period), so that no bee was able to forage the following day.

\subsection{Observations}

The behavioural observations lasted from 12 July until 3 August 1996, between 11.00 and 15.00 hours, and between 22.00 and 02.00 hours. Observations were performed during days with either very good weather conditions, when bees were able to fly and forage, or very bad weather conditions, when they were not able to fly, and during the following nights. Each period of observation lasted for $1 \mathrm{~h}$ and focused on a single bee. We were able to keep the focal bee under observation for the entire 1-h session except for short periods when she entered hidden regions of the hive. These periods amounted to only $2 \%$ of the observation time, on average, during days of good weather, $0.9 \%$ during nights following good weather, $0.7 \%$ during days of bad weather conditions and $0.1 \%$ during nights after bad weather. Each bee was observed with a magnifying glass and additional red light whenever necessary.

As focal workers were chosen randomly for observation from among the marked bees noted at the beginning of the individual observation period, it sometimes happened that a bee was observed more than once. The focal bees were observed on the day they were classified as foodstorers and also on the following bad weather day. Food-storer bees were observed for a total of $103 \mathrm{~h}$. The recorded behavioural patterns of the bees were analysed with a computer program specifically designed for these experiments. Results were expressed as percentage of total observation time for some behavioural categories (unproductivity, patrolling/transporting), and as the number of events per hour for others (inspecting cells, cleaning cells, visiting honey or pollen cells). Also, the mean duration and total number of trophallactic contacts were recorded.

\subsection{Behavioural classifications}

\subsubsection{Unproductivity}

This category comprised the two categories 'absolutely inactive' and 'idle', defined as follows. A bee is absolutely inactive if it stands motionless without any detectable movement of antennae or legs, or remains in an empty cell without any detectable movement of the abdomen [19]. If the bee stands and moves its antennae and legs or walks around very slowly with no recognizable intended direction and a velocity of less than $5 \mathrm{~mm}$ per second, it is being idle.

\subsubsection{Patrolling/Transporting}

The bee walks across the comb with a speed of more than $5 \mathrm{~mm}$ per second.

\subsubsection{Inspecting cells}

The bee bends her head over a cell and 'looks' into it for not longer than $2 \mathrm{~s}$ [19]. Each visit of a cell was recorded as one action. The times the bee spent walking from one cell to another was recorded as patrolling.

\subsubsection{Cleaning cells}

The whole bee stays in an empty cell and moves around inside.

\subsubsection{Trophallactic contacts (receiving and donating)}

One bee (recipient) puts her tongue between the mandibles of another bee (donor) for more than $2 \mathrm{~s}$.

\subsubsection{Visiting honey and pollen cells}

The bee inserts her head and her thorax into a cell containing honey or pollen and her abdomen is moving.

\subsubsection{Attending the queen}

The bee has contact with the queen, touches her with antennae or feeds her. 


\subsubsection{Nursing brood}

The bee inserts her head and thorax into a cell within the brood area for more than $2 \mathrm{~s}$ while her abdomen pulsates. The presence of larvac was checked afterwards.

\subsubsection{Other activities}

Other activities include the following behaviours: all kinds of dancing, following dancers, self-grooming, grooming other hive mates, ventilating, aggressive bchaviour, being attacked, being shaken, manipulating wax, guarding and flying.

\subsection{Statistics}

Means and standard deviations are given. There were 26 observation periods during day and night and during good and bad weather conditions. Data were tested by the Mann-Whitney U-Test. The level of statistical significance was set at $P<0.05$. To test the distribution of the number of trophallactic contacts, they were tested with the $\mathrm{Chi}^{2}$ test.

\section{RESULTS}

During the 23 days of observations, a total of 102 marked bees were classified as food-storers (bees that received nectar from foragers on the dance floor, then transported it to the upper parts of the hive and stored it or fed it to hive mates). All the identified food-storers were between 13 and 19 days old (figure 1). From the group of food-storers our focal bees were chosen randomly.

\subsection{Temperature}

The temperature of the room where the hive was located was kept constantly in the range $22-25^{\circ} \mathrm{C}$. The temperature of the broodnest was regulated by the bees to $33.5 \pm 0.2{ }^{\circ} \mathrm{C}$. The use of the rain machine caused a drop in temperature in the nonbroodnest areas (the honey stores and lowest comb) of about $7-8^{\circ} \mathrm{C}$.

\subsection{Location (figure 2)}

The distribution of the food-storers on the food stores, the broodnest and the empty comb depended on weather and time of day. During days with good weather conditions food-storer bees spent $58 \%$ of the observed time on the empty comb near the hive entrance. On sunny days food-storer bees were observed performing flights about $6 \%$ of the time (data not shown in figure 2). During days with bad weather conditions and during all night-time observation periods food-storer bees spent between 82 and

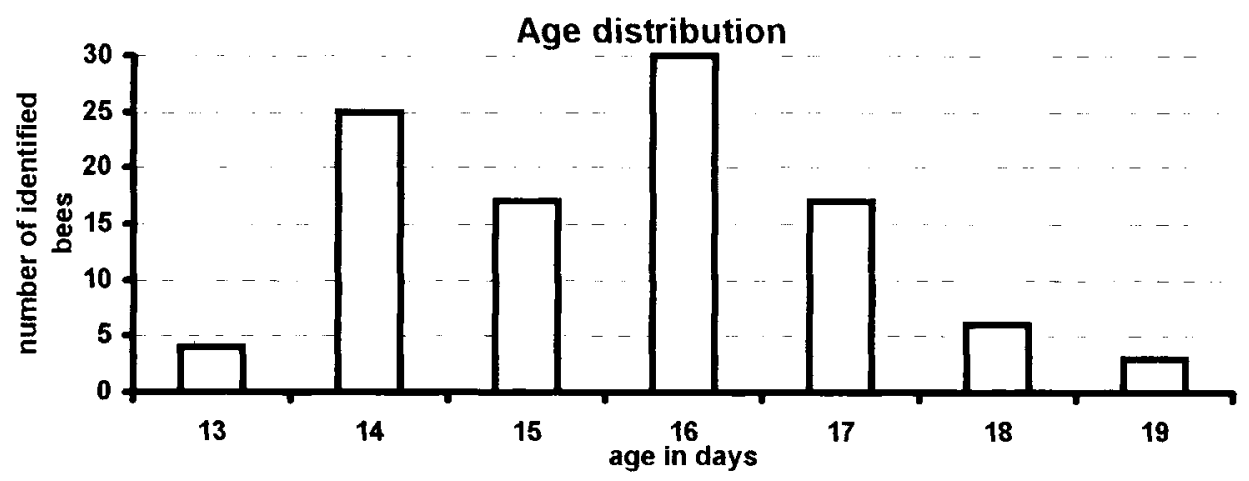

Figure 1. Age distribution of bees identified as food-storers (bees observed receiving nectar on the dance floor). 

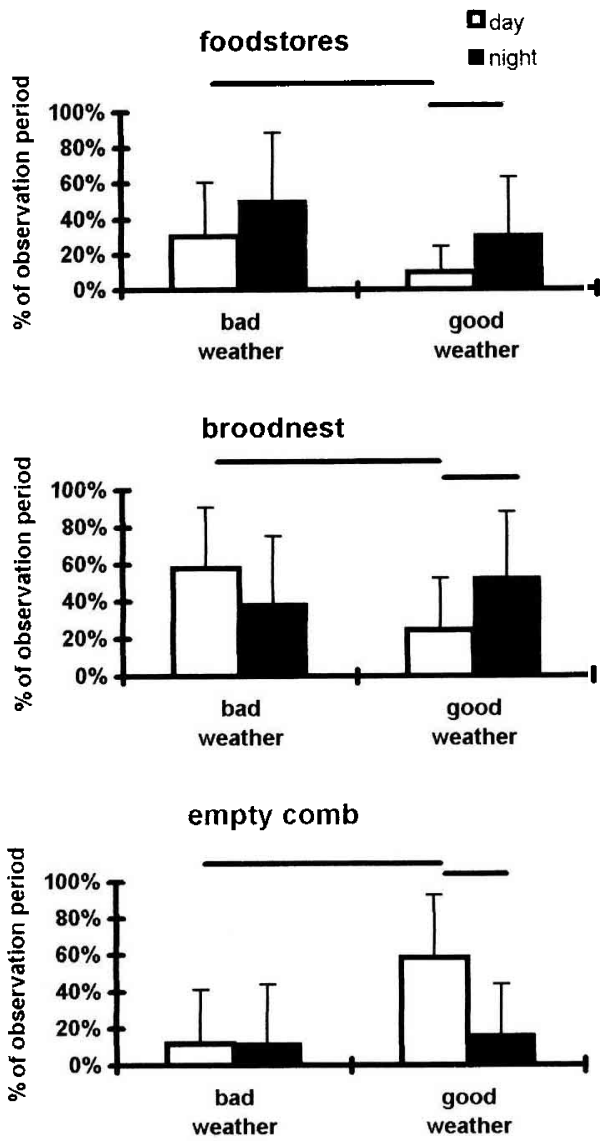

Figure 2. Location of food-storer bees observed in various regions of the hive. Length of stay is shown as a percentage of the observation period. Means and standard deviations are shown. Horizontal lines above columns indicate significant differences $(P<0.05)$.

$89 \%$ of the time in the broodnest area and on the honey stores in the upper parts of the hive.

\subsection{Behavioural patterns}

\subsubsection{Unproductivity (figure 3)}

Food-storer bees had significantly longer periods of inactivity during nights after good weather conditions and during days and nights with bad weather conditions than during days with good weather conditions. Also, during all nights and during days with bad weather conditions, food-storer bees were idle for significantly longer periods than during days with good weather conditions. Unproductive periods occurred significantly more often during nights with good weather conditions and during days and nights with bad weather conditions (between 68 and $72 \%$ of observation time) than during days with good weather conditions $(10 \%)$. The extent of the night-time periods of unproductivity did not depend on the level of activity of the food-storers during the previous day.

\subsubsection{Patrolling/Transporting (figure 4)}

Food-storer bees spent more than half of the observed time patrolling during days with good weather conditions. They were observed patrolling on the lowest comb ( $30 \%$ of the observation time), through the broodnest $(15 \%)$ and on the honey stores (5\%). During all nights and during days with bad weather conditions patrolling was observed significantly less often (4-6\% of observation time).

\subsubsection{Inspecting cells (figure 4)}

During days with good weather conditions food-storer bees inspected cells significantly more often than during all other periods. Altogether the 103 food-storer bees were observed making 684 cell inspections on the lowest comb, 347 cells in the broodnest and 184 among the honey stores during days with good weather conditions. In the course of the 103 observation periods food-storer bees were observed to have inspected a total number of 2955 cells (1 215 during days with good weather and 1740 during days of bad weather and during nights). 


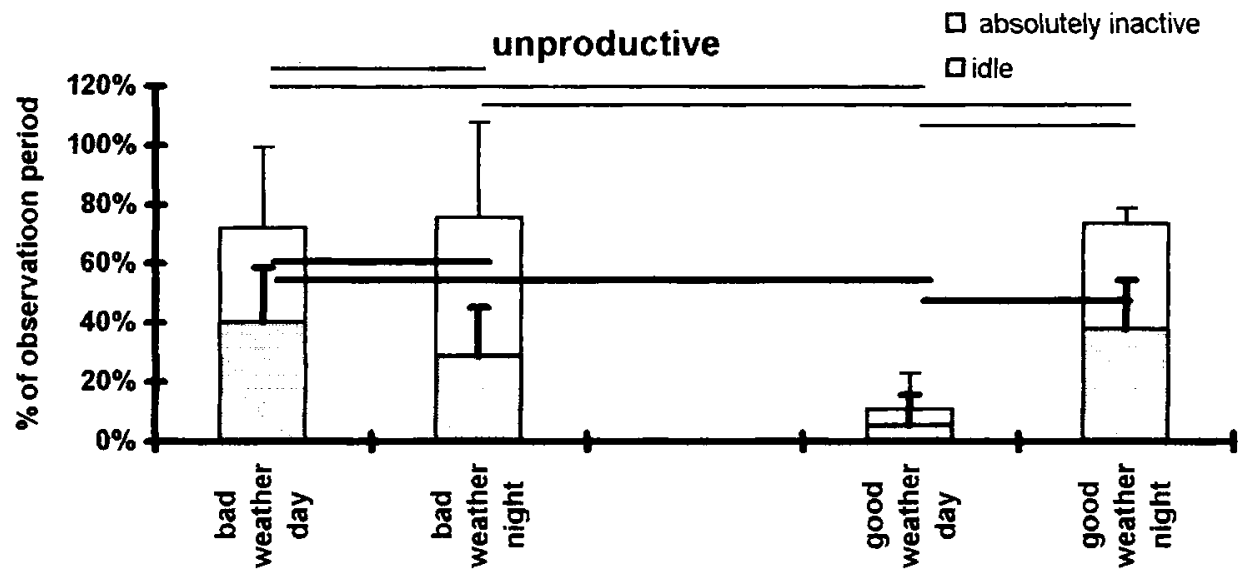

Figure 3. Unproductive periods ('inactive' and 'idle' behaviours combined) of food-storer bees. Means and standard deviations are shown. Thin horizontal lines above columns indicate significant differences for the category 'absolutely inactive', fat lines for the category 'idle' $(P<0.05)$.

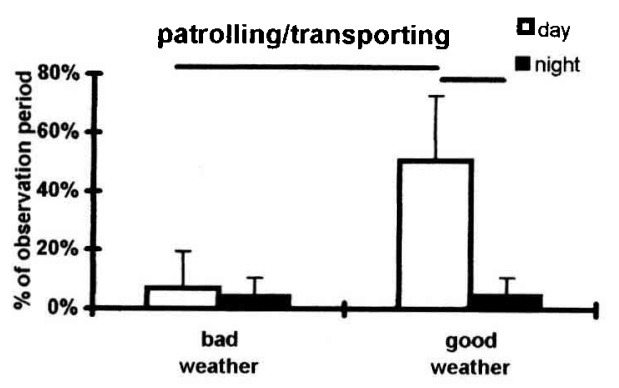

\subsubsection{Cleaning cells (figure 4)}

Food-storer bees were observed cleaning cells significantly more often during days with good weather conditions than during days with bad weather conditions or during the night. On days with good weather conditions 94 out of 101 cell cleaning acts occurred on the lowest comb.

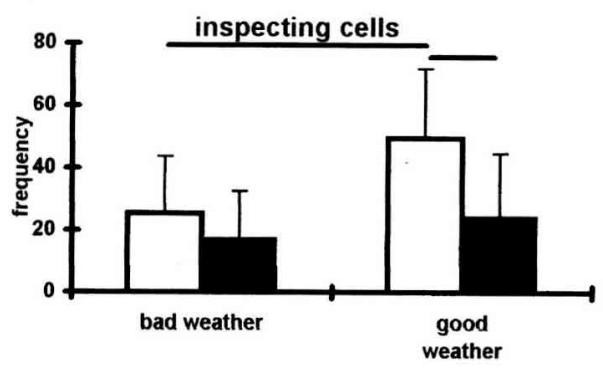

\subsubsection{Trophallactic contacts (receiving and donating) (figure 5, table I)}

In all, $92 \%$ of the focal bees received food during observation times. The counts of receiving and donating acts at the three different locations and four daytime and weather conditions were not distributed at random $\left(\mathrm{Chi}^{2}\right.$-test, see table I). Trophallactic receiving contacts occurred more often

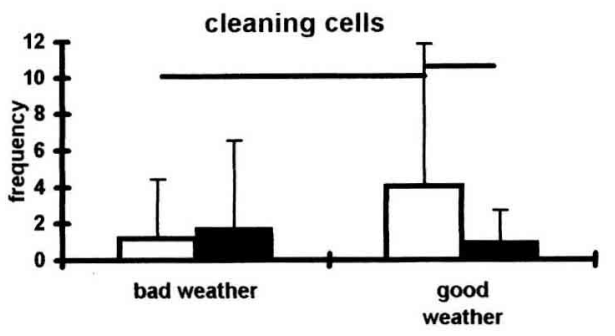
and lasted significantly longer during days

Figure 4. Typical activities of food-storer bees. Means and standard deviations are shown. The frequencies are expressed as times per observation period. Horizontal lines above columns indicate significant differences $(P<0.05)$. 


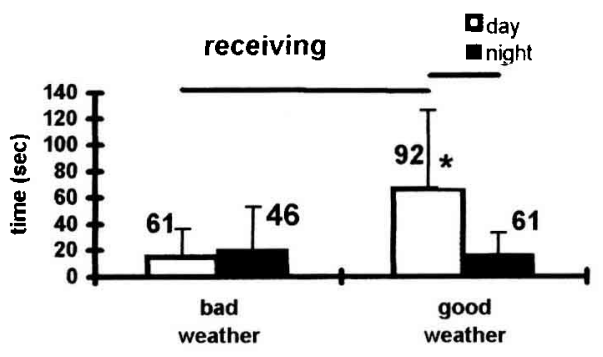

donating

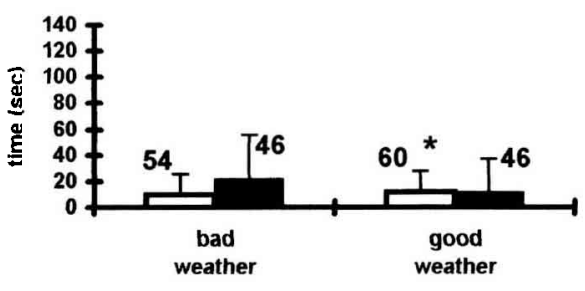

Figure 5. Mean duration of trophallactic activities (receiving and donating) by food-storer bees. Data of all bees observed were used for calculation, even if they did not show this specific behaviour. Numbers above columns show the percentage of bees performing this task. Horizontal lines above columns indicate a significant difference between weather conditions or day versus night, and a pair of asterisks indicates a significant difference between receiving and donating. The level of significance was set at $P<0.05$. with good weather conditions than during days with bad weather conditions or during the night. On good weather days a total of 180 receiving acts were observed (see table I), 103 of which occurred on the lowest comb, 57 in the broodnest, 15 among the honey stores, and five in other parts of the hive. During nights after good weather conditions and during days and nights with bad weather conditions, receiving acts were less frequent and they occurred mainly in the broodnest (table I). When the time spent donating food was analysed, no significant differences were found based on weather conditions or day versus night (figure 5). During days with good weather conditions the mean duration of donating and receiving food differed significantly, whereas no significant differences were apparent under the other conditions (figure 5).

\subsubsection{Visiting honey and pollen cells (table II)}

Food-storer bees were observed visiting honey cells more often during days with good weather than during days with bad weather or during all nights. In total they were observed visiting honey cells 173 times. In $103 \mathrm{~h}$ of observation food-storer bees were recorded visiting pollen cells 12 times,

Table I. Number of receiving and donating acts and the locations where they occurred.

\begin{tabular}{lccccc}
\hline & Broodnest & Honeystores & Lowest comb & Total (103 h) \\
\hline Receiving & & & & & \\
Bad weather & day & 19 & 19 & 1 & 38 \\
Bad weather & night & 37 & 14 & 0 & 51 \\
Good weather & day & 57 & 15 & 103 & 180 \\
Good weather & night & 32 & 6 & 2 & 40 \\
Donating & & & & & \\
Bad weather & day & 23 & 6 & 0 & 30 \\
Bad weather & night & 20 & 7 & 3 & 58 \\
Good weather & day & 30 & 8 & 20 & 21 \\
Good weather & night & 14 & 6 & 1 & \\
\hline
\end{tabular}

Receiving: $\mathrm{Chi}^{2}=124.96, \mathrm{df}=6, P<0.001 ;$ donating: $\mathrm{Chi}^{2}=22.25, \mathrm{df}=6, P<0.001$. 
Table II. Frequency (events per hour) of food-storer bees visiting honey and pollen cells.

Honey cells Pollen cells

\begin{tabular}{lccc}
\hline Bad weather & day & 0.61 & 0.07 \\
Bad weather & night & 0.77 & 0.11 \\
Good weather & day & 1.68 & 0.16 \\
Good weather & night & 1.00 & 0.11 \\
\hline
\end{tabular}

and a bee stayed in a pollen cell, on average, for $32.7 \pm 13.57 \mathrm{~s}$.

\subsubsection{Attending the queen and nursing brood}

During all $103 \mathrm{~h}$ of observation, a total of 22 instances of queen care by ten food-storers was observed. Food-storer bees were observed nursing the brood very infrequently; the rate ranged from $0.03 \%$ of observation time on nights following bad weather to $0.2 \%$ of observation time on days with good weather.

\subsubsection{Other activities}

Frequencies of all activities other than those listed above were pooled. Under the various experimental conditions, food-storer bees spent between 14.3 and $23.4 \%$ of all of the observation time on these other activities.

\section{DISCUSSION}

\subsection{Influence of weather}

A high influx of nectar into the hive during good weather conditions requires foodstorer bees to unload the returning nectar foragers. Seeley [22] described this behaviour as the link between two labour cycles, the forage cycle and the storage cycle. The link occurs on the dance floor, next to the hive entrance. Food-storer bees and foragers work together as a team during good forag- ing conditions. In our experiment, under such conditions food-storer bees received food, mainly on the dancing floor, a multiple of times compared to during bad weather conditions. They were patrolling and transporting food about $50 \%$ of the observed time and inspected cells, perhaps searching for a cell in which to deposit the transported nectar. They did this significantly more often than during days with bad weather conditions or during nights. We cannot state with certainty that the bee was then depositing nectar inside the cell but this seems to be very likely.

When foraging was not possible, i.e. during nights and during days with bad weather conditions, the focal bees did not take over other tasks typical of middle-aged bees, such as undertaking, guarding or wax-working [23]. Also the behaviour of food-storer bees clearly differed from the behaviour of nurses or foragers [16]. Food-storers very seldom nursed the brood (only $0.03-0.2 \%$ of the observed time) or performed flights (only $6 \%$ of the observation time during days with good weather conditions). Instead of looking for other duties under short-term bad weather conditions food-storer bees spent about $70 \%$ of the observation time being unproductive. Remaining unproductive can conserve honey stores for the colony, as many activities of bees require lots of energy [6]. For foragers, when food collection was not possible, long unproductive periods ( $70 \%$ of the observation time) were reported [16], and it was shown that under short-duration bad weather conditions or at night foragers, too, typically do not switch to other tasks in the colony. Thus, regarding the level of activity and unproductivity, foragers and food-storers behave similarly.

\subsection{Day and night}

For foragers, Crailsheim et al. [4] reported a pronounced day-night rhythm during good weather conditions. As described above, all 
activities of food-storers directly related to the income of food were reduced during night hours and replaced by unproductivity.

In contrast, during bad weather, when both day and night were periods without food income, no significant day-night differences were observed in any of the measured parameters, except that the food-storers were completely inactive slightly more of the time during the night. This might be attributable to generally lower activity during a night after a rainy day. But it might also be related to the fact that in bees of this age (15 days) a circadian rest-activity rhythm develops [20].

\subsection{Location}

When there was the opportunity for foodstorers to work, they were mostly on the empty comb where the dancing floor was located and they could receive nectar from foragers. The queen excluder did not seem to hinder them from depositing the food in the food storage area above. Also, the general distribution of these middle-aged bees seemed not to be influenced very much by this obstruction; it matched that found in a big colony [5], where middle-aged bees spent about half of their time in the broodnest.

One explanation for this pattern is temperature preference. Heran [8] and Crailsheim et al. [5] demonstrated that worker bees are able to discriminate different temperatures in an arena and that very young bees stay in areas with higher temperatures, compared to foragers. The presence of nurses in the warm broodnest is caused at least partly by their general preference for higher temperatures [5]. As the temperature preference declines with age and nurses are only somewhat younger than food-storers, it seems reasonable to conclude that food-storers prefer the warmer areas of the hive during times when foraging is not possible. In this regard they clearly differ from foragers, who spend their unemployed time in the colder areas of the hive.

Another reason for preferred locations might be trophallaxis, as already discussed for drones [5] and as discussed below.

\subsection{Trophallaxis}

The observed food-storer bees had most of their receiving trophallactic contacts in the empty comb area, where they spent most of the time during good weather days. During days with bad weather conditions and at night, food-storer bees spent more than $82 \%$ of the observation time in the warm broodnest and on the honey stores, the same areas that nurse bees occupy [15, 16]. Most trophallactic contacts of food-storer bees during times when foraging was not possible occurred in the broodnest area. Foodstorers donated food during days and nights with good weather three times less frequently than nurses [16]. It is very likely that nurses, staying preferentially in the broodnest, feed proteinaceous brood food to the food-storer bees, as bees of all ages are supplied with their secretions [2]. To what extent, if any, food-storers depend on this feeding is not clear, since it is known that workers of the age of food-storers produce proteinaceous secretions themselves and feed them to their companion bees $[9,11]$. Food-storers were observed in pollen cells very rarely. Nurses are also known to visit pollen cells infrequently, but when they do visit nurses spend about six times longer in the cell than the food-storers in our investigation did [4].

The exchange of food within a honeybee colony is very intense. Nixon and Ribbands [14] showed that a small quantity of food collected by foragers can become widely distributed among the members of a colony within a few hours. This exchange functions not only to promote nutrition but also as a means of communication between the members of the colony and as the basis for their 
social organisation. Camazine et al. [1] discussed trophallaxis as a possible way of communicating the information of pollen reserves from nurse bees to foragers. Most of the donating trophallactic interactions of the food-storer occur in the broodnest. Is information important for the nurses transferred in this way?

Nurses spent less than half as much time nursing the brood during bad weather conditions as in good weather conditions [16]. The authors interpret this as the conserving of protein (jelly) in preparation for a possible period of food shortage. But how do the nurses perceive a shortage of incoming nectar and pollen so quickly, when there are still plenty of stores? It might be that the beginning of a period of shortage is indicated by the increased presence of foodstorers in the broodnest and reduced trophallactic contacts between food-storers and the bees there (probably nurses). Our results show that compared to days with good weather, during days with bad weather conditions and the following nights, there exists a tendency of reduced trophallactic contacts between food-storers and the bees in the broodnest, and an increased presence of the food-storer bees in the broodnest area. Based on our behavioural observations we can only make statements about the frequency and durations of trophallactic tasks and not about the amount of food exchanged [13] or its quality [3]. Korst and Velthuis [10] found that less than $5 \%$ of trophallactic interactions result in actual food transfer, and they supposed that the majority of trophallactic contacts serve communication purposes rather than being idle food transfers. Our data may be related to such a transfer of information, but more detailed and quantitative experiments will be necessary to investigate this topic.

\section{ACKNOWLEDGEMENT}

We acknowledge the support of Dr Karl Pfeiffer for data computation.
Résumé - Effets à court terme de conditions simulées de mauvais temps sur le comportement diurne et nocturne des abeilles magasinières (Apis mellifera carnica Pollmann). Comme nous l'avons montré lors d'études précédentes, le comportement des nourrices et des butineuses est fortement influencé à court terme par les changements de temps. Le comportement des abeilles qui réceptionnent la nourriture (magasinières), caste fonctionnelle intermédiaire entre les nourrices et les butineuses, a été étudié sur environ 5000 abeilles d'une ruche d'observation à trois cadres durant l'été 1996. Les observations ont eu lieu tous les jours de beau temps et de mauvais temps (journée pluvieuse) et dans chacune des nuits suivantes. Les magasinières, qui ont été caractérisées par leur comportement (réception pendant plus de $5 \mathrm{~s}$ de la nourriture apportée par des butineuses marquées et transport du nectar dans la zone de stockage du miel) avaient un âge compris entre 13 et $19 \mathrm{j}$ (figure 1).

Les jours de beau temps et de forte rentrée de nectar, les magasinières se montraient fort actives. Elles passaient plus de $50 \%$ du temps d'observation à patrouiller et à transporter le nectar de la surface de danse, située près du trou de vol dans la partie supérieure de la ruche (figure 2). Les jours de mauvais temps et la nuit, y compris dans les périodes sans rentrée de nectar, les magasinières passaient près de $70 \%$ du temps d'observation à ne rien faire, contre $10 \%$ les jours de beau temps (figure 3). Elles n'entreprenaient pas d'autres activités, telles que la garde de la colonie ou la production de cire, qui sont des activités typiques de cette classe d'âge. Ce comportement pourrait correspondre à une économie d'énergie pour la colonie. Par leur comportement, elles se distinguaient nettement des nourrices et des butineuses. Ainsi ce groupe d'abeilles n'a été que très rarement observé en train de nourrir le couvain $(0,3 \%)$ ou de s'envoler ( $6 \%$ uniquement par beau temps).

Toutes les activités des magasinières sont directement reliées à la rentrée de nectar les jours de beau temps. Un rythme nycthémé- 
ral net n'a pu être mis en évidence que lorsque le nectar afflue.

Puisque les magasinières ont un comportement lié à la rentrée de nectar, elles passaient, les jours de beau temps, $58 \%$ du temps d'observation à proximité du trou de vol, où elles cherchaient un contact avec les butineuses qui rentraient (figure 5). Quand il faisait mauvais et la nuit, elles ne passaient là que 12 à $16 \%$ du temps et environ $40 \%$ sur le nid à couvain et plus de $30 \%$ sur les rayons à miel, qui sont les endroits les plus chauds de la ruche. Cette différence pourrait s'expliquer par leur préférence pour les températures élevées.

La plupart des échanges trophallactiques entre magasinières et butineuses étaient enregistrés près du trou de vol par beau temps et sur le nid à couvain lorsqu'il n'y avait pas de rentrée de nectar, mais les contacts y étaient alors beaucoup moins nombreux (tableau I). Cette diminution de la trophallaxie par mauvais temps et/ou la présence simultanée de nombreuses magasinières sur le nid à couvain pourrait représenter un signal à destination des nourrices pour qu'elles distribuent la nourriture avec plus de parcimonie. (C) Inra/DIB/AGIB/Elsevier, Paris

\section{comportement social / division travail / condition météorologique / jour et nuit}

\section{Zusammenfassung - Der Einflu $\beta$ von kurzzeitigen simulierten Wetterände- rungen auf das Verhalten von Futterab- nehmerinnen der Honigbiene während Tag und Nacht (Apis mellifera carnica Pollmann). Wie wir in vorausgegangenen Untersuchungen zeigen konnten, wird das Verhalten von Ammen und Sammlerinnen bereits durch kurzzeitige Wetteränderungen stark beinflußt. Das Verhalten von Fut- terabnehmerinnen, die als Funktionskaste zwischen Ammen und Sammlerinnen lie- gen, wurde im Sommer 1996 in einem 3-Waben-Beobachtungsstock mit etwa 5000 Bienen untersucht. Die Beobachtun- gen erfolgten an Tagen mit guten und schlechten (ein Regentag) Wetterbedin- gungen und in den jeweils folgenden Näch-}

ten. Die Futterabnehmerinnen, die durch ihr Verhalten identifiziert wurden (Futterabnahme von markierten Sammlerinnen für mehr als 5 Sekunden und Transport des Nektars zu den Honiglagern), waren zwischen 13 und 19 Tagen alt.

An Tagen mit guten Wetterbedingungen, und einem hohen Nektareinstrom, zeigten sich die Futterabnehmerinnen sehr aktiv. Mehr als $50 \%$ der beobachteten Zeit verbrachten sie mit Patrouillieren und dem Transport von Nektar vom Tanzboden, der in der Nähe des Stockeingangs lag, zu den Honiglagern, im oberen Teil des Stockes. An Tagen mit schlechten Wetterbedingungen und in allen Nächten, also zu Zeiten ohne Nektareinstrom, verbrachten Futterabnehmerinnen ungefähr $70 \%$ der Beobachtungszeit unproduktiv (im Gegensatz zu $10 \%$ an Schönwettertagen). Futterabnehmerinnen übernahmen auch keine anderen Tätigkeiten, wie Wächterdienst oder Wachsproduktion, die für Bienen dieses Alters typisch wären. Dieses Verhalten könnte Energie für die Kolonie sparen. Die Futterabnehmerinnen unterschieden sich in ihrem Verhalten auch deutlich von Ammen oder Sammlerinnen. So konnte diese Gruppe nur sehr selten beim Füttern der Brut $(0,3 \%)$ oder bei Ausflügen (nur an Schönwettertagen, $6 \%$ ) beobachtet werden.

Alle Tätigkeiten der Futterabnehmerinnen sind direkt verknüpft mit dem Nektareinstrom an Schönwettertagen. Ein ausgeprägter Tag-Nacht Rhythmus konnte nur dann registriert werden, wenn untertags ein Einstrom von Nektar gegeben war.

Da Futterabnehmerinnen in ihrem Verhalten vom Nektareinstrom abhängig sind verbrachten sie an Schönwettertagen $58 \%$ der beobachteten Zeit in der Nähe des Stockeinganges, wo sie Kontakt mit den zurückkehrenden Sammlerinnen suchten. An Schlechtwettertagen und in allen Nächten verbrachten sie dort hingegen nur 12 bis 16 $\%$ der Zeit, aber etwa $40 \%$ im Brutnest und mehr als $30 \%$ auf den Honiglagern, den wärmsten Bereichen des Stocks. Dieser Unterschied könnte durch ihre Vorliebe für höhere Temperaturen erklärt werden. 
An Schönwettertagen waren die meisten trophallaktischen Kontakte, bei denen Futterabnehmerinnen Futter bekamen, in der Nähe des Stockeinganges zu verzeichnen. Dies entspricht der Aufgabe dieser temporären Kaste. Zu Zeiten ohne Futtereinstrom konnten die meisten trophallaktischen Kontakte im Brutnest beobachtet werden, dennoch waren die Kontakte zu diesen Zeiten geringer als an Schönwettertagen. Dieser Rückgang trophallaktischer Kontakte bei Schlechtwetter und/oder die gleichzeitige Anwesenheit vieler Futterabnehmer im Brutnest könnte ein Signal für die Ammenbienen darstellen, mit den Futterresourcen sparsamer umzugehen. (C) Inra/DIB/AGIB/ Elsevier, Paris

\section{Sozialverhalten / Arbeitsverteilung / Wetter / Tag und Nacht}

\section{REFERENCES}

[1] Camazine S., Crailsheim K., Hrassnigg N., Robinson G.E., Leonhard B., Kropiunigg H., Protein trophallaxis and the regulation of pollen foraging by honey bees (Apis mellifera L.), Apidologie 29 (1998) [13-126.

12] Crailsheim K., The flow of jelly within a honeybee colony, J. Comp. Physiol. B. 162 (1992) 681-689.

[3] Crailsheim K., Trophallactic interactions in the adult bee (Apis mellifera L.), Apidologie 29 (1998) 189-204.

14] Crailsheim K., Hrassnigg N., Stabentheiner A. Diurnal behavioural differences in forager and nurse honey bees (Apis mellifera carnica Pollm), Apidologie 27 (1996) 235-244.

15] Crailsheim K., Eggenreich U., Ressi R., Szolderits M.J., Temperature preference of honeybee drones (Apis mellifera L.), Entomol. Gen. (1999) in press.

[6] Crailsheim K., Stabentheiner A., Hrassnigg N., Leonhard B., Correlation of oxygen consumption and activity at different ambient temperatures in isolated honeybees (Apis mellifera), Entomol. Gen. (1999) in press.

[7] Frisch K. von, Tanzsprache und Orientierung der Bienen, Springer, Berlin, Heidelberg, New York, 1965.

[8] Heran H., Untersuchungen über den Temperatursinn der Honigbiene (Apis mellifica) unter besonderer Berücksichtigung strahlender Wärme, Z. Vergl. Physiol. 34 (1952) 179-206.
19 Hrassnigg N., Crailsheim K., Adaptation of hypopharyngeal gland development to the brood status of honeybee (Apis mellifera L.) colonies, J. Insect Physiol. 44 (1998) 929-939.

[10] Korst P.J.A.M., Velthuis H.H.W., The nature of trophallaxis in honeybees, Insectes Soc. 29 (1982) 209-221.

[11] Lass A., Crailsheim K., Influence of age and caging upon protein metabolism, hypopharyngeal glands and trophallactic behavior in the honey bee (Apis mellifera L.), Insectes Soc. 43 (1996) 347-358.

112] Lindauer M., Ein Beitrag zur Frage der Arbeitsteilung im Bienenstaat, Z. Vergl. Physiol. 34 (1952) 299-345.

1131 Moritz R.F.A., Hallmen M., Trophallaxis of worker honeybees (Apis mellifera $\mathrm{L}$.) of different ages, Insectes Soc. 33 (1986) 26-31.

[14] Nixon H.L., Ribbands C.R., Food transmission within a honey bec community, Proc. R. Soc. B. 140 (1952) 43-50.

[15] Pfeiffer K.J., Crailsheim K., The behaviour of drifted nurse honeybees, Insectes Soc. 46 (1999) 34-40.

[16] Riessherger U., Crailsheim K., Short-term effect of different weather conditions upon the behaviour of forager and nurse honey bees (Apis mellifera carnica Pollmann), Apidologie 28 (1997) 411-426.

[17] Rösch G.A., Untersuchungen über die Arbeitsteilung im Bienenstaat, 1. Teil: Die Tätigkeiten im normalen Bienenstaate und ihre Bezichung zum Alter der Arbeitsbienen, Z. Vergl. Physiol. 2 (1925) 571-631.

[18] Rösch G.A., Untersuchungen über die Arbeitsteilung im Bienenstaat, 2. Teil: Die Tiatigkeit der Arbeitsbienen unter experimentell veränderten Bedingungen, Z. Vergl. Physiol. 12 (1930) 1-70.

[19] Sakagami S.F., Untersuchungen über die Arbeitsteilung in einem Zwergvolk der Honigbiene. Beiträge zur Biologie des Bienenvolkes, Apis mellifera L., Jpn. J. Zool. 11 (1953) 117-185.

[20] Sauer S., Menna-Barreto L., Kaiser W., The temporal organization of rest and activity in newly emerged honey bees kept in isolation - initial results, Apidologie 29 (1998) 445-447.

[21] Seeley T.D., Adaptive significance of the age polyethism schedule in honcybee colonies, Behav. Ecol. Sociobiol. 11 (1982) 287-293.

[22] Seeley T.D., Social foraging in honey bees: how nectar foragers assess their colony's nutritional status, Behav. Ecol. Sociobiol. 24 (1989) 181-199.

123] Trumbo S.T., Huang Z.-Y., Robinson G.E., Division of labor between undertaker specialists and other middle-aged workers in honey bec colonies, Behav. Ecol. Sociobiol. 41 (1997) 151-163.

[24] Winston M.L., The Biology of the Honey Bee, Harvard University Press, Cambridge, MA, USA, 1987. 